\title{
BUDAPESTI DUNA-HIDAK
}

\author{
A HIDAK JELENLEGI ÁLLAPOTA AZ ELMÚLT 40 ÉV VIZSGÁLATAINAK \\ TÜKRÉBEN
}

DR. SZITTNER ANTAL*

\begin{abstract}
A Budapesti Müszaki Egyetem Acélszerkezetek Tanszéke kb. 1955 óta foglalkozik tartószerkezetek erőjátékának kísérleti vizsgálatával. Jelen tanulmány a budapesti hidak építése, felújítása és forgalomba helyezése során végzett érdekesebb mérési feladatokat és azok eredményeit ismerteti. Bemutatjuk az Erzsébet híd szereléséhez kapcsolódó modellkísérletet, a híd próbaterhelésénél a merevítőtartó nyolc övlemezes keresztmetszetében mért feszültségeloszlást, a Szabadság híd megroppant oszlopának helyreállításával és a próbaterheléssel kapcsolatos munkánkat, a mérések alapján levont következtetéseket. Ismertetjük a Lánchíd erősen korrodált lánclemezei korróziós károsodásának mérésére alkalmazott mérési módszert és annak eredményeit. Beszámolunk a Déli Vasúti Duna-hídon a fötartók és hossztartók fáradás szempontjából várható élettartamának megállapítására vonatkozó vizsgálatokról, azok eredményéről és végül ismertetjük a Petőfi híd sarucseréjével kapcsolatos előkészítő és végrehajtást irányító munkánkat. Ebben a több évtizedes munkában legfontosabb munkatársaim: Dr. Kálló Miklós, Kaltenbach László, Dr. Köröndi László, Dr. Kristóf László és Dr. Papp Ferenc voltak, akiknek értékes segítségéért ezúton szeretnék köszönetet mondani.
\end{abstract}

\section{ELŐZMÉNYEK}

1945-ben, Budapest ostrománál a német csapatok az összes budapesti Duna-hidat (5 közúti és 2 vasúti híd) felrobbantották.

A felrobbantott hidak közül három közúti híd (Ferencz József híd, Lánchíd, Petőfi híd) kisebb változtatásokkal, eredeti formában, részben az eredeti, részben más hidak roncsanyagából épült újjá. Két közúti híd (Margit híd és Erzsébet híd) és a vasúti hidak újjáépítése eredeti helyükön új szerkezettel történt. Az újjáépítés 1964-re fejeződött be. A Duna budapesti szakaszán azóta három új, közúti híd épült (Árpád híd, Hárosi M0 híd és Lágymányosi híd).

* A Budapesti Múszaki és Gazdaságtudományi Egyetem Acélszerkezetek Tanszékének ny. tud. fömunkatársa 
A bécsi Reichsbrücke 1976-ban történt katasztrófája után indult meg a budapesti Duna-hidak rekonstrukciója, és ettől kezdve kapcsolódott be fokozott mértékben ebbe a munkába, elsősorban erőtani mérések vonatkozásában, a Budapesti Müszaki Egyetem Acélszerkezetek Tanszéke, amely részt vett a hidak felülvizsgálatában, a vizsgálatok során adódó erőtani problémák mérések segítségével történő megoldásában és az új hidak próbaterhelésében.

Ezek az erőtani mérések elsősorban a régebbi hidaknál, illetve a részben eredeti anyagból újjáépült hidaknál jelentkeztek, és ezek legérdekesebb eredményeiről, valamint a vizsgálatok alapján a hidakkal kapcsolatban javasolt teendőkről és azok indoklásáról a következőkben számolunk be.

\section{MARGIT HÍD}

Az eredeti Margit híd Budapest második állandó hídjaként 1872-76 között, Gouin (Párizs) tervei alapján épült 6 ívszerkezetủ medernyílással és 2 ugyancsak ívszerkezetủ parti nyílással. A medernyílásokat felrobbantották. Ezeket 1947-1948-ban az eredetitől eltérő formában építették újjá. A parti nyílások épen maradtak (1. ábra). Az 1976-ban megindult hídrekonstrukció-sorozat keretében először a Margit hídra került sor. A még eredeti elemeket tartalmazó pesti parti nyílás erőtani viselkedésének vizsgálatáról és annak eredményeiről a IABSE 1983. évi, Velencében tartott szimpóziumán számoltunk be [1]. A vizsgálat kedvező erőtani eredményei ellenére [2] a híd anyaga (hegeszvas) és a megnövekedett forgalom miatt a két parti nyílás eredeti szerkezetét is átépítették.

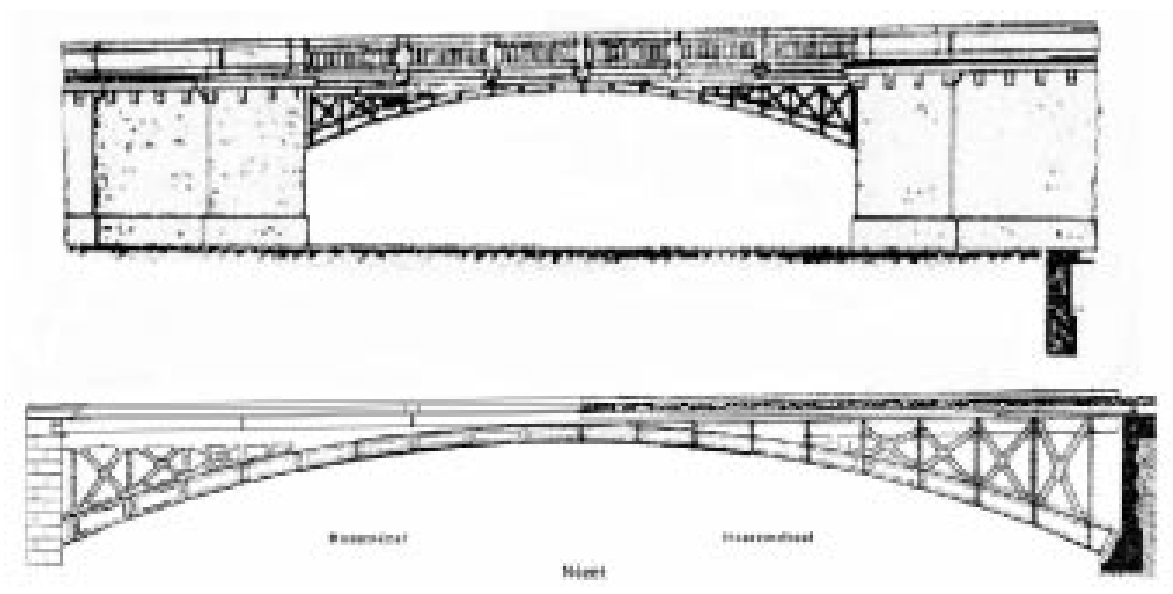

1. ábra. A Margit híd eredeti parti nyílásának vázlata 


\section{SZÉCHENYI-LÁNCHÍD}

A híd eredeti formájában 1839-1849 között, Budapest első állandó hídjaként, gróf Széchenyi István kezdeményezésére, W. Th. Clark tervei alapján, A. Clark kivitelezésében, építésének idején a legnagyobb nyílású lánchídként épült. Az eredeti híd kovácsolt lánclemezekkel, öntöttvas kereszttartókkal, fa pályaszerkezettel, külön merevítőtartó nélkül készült (2. ábra). A megnövekedett forgalom és a nem megfelelő merevség miatt az eredeti hidat 1913-15 között, Kherndl Antal statikai számítása, Beke József és Gállik István tervei alapján, külső megjelenésében az eredetivel megegyezően klasszicista stílusban, de szerkezeti megoldásaiban attól eltérô, a mai forgalom viselésére is alkalmas formában építették át (3. ábra).

Az 1945-ben felrobbantott híd újjáépítésénél csak a régi falazatokat és a régi lánclemezek legnagyobb részét használták fel újra.

1987-ben került sor a híd első nagyobb rekonstrukciójára. Ennek során vált láthatóvá elsősorban a horgonykamrákban lévő lánclemezek erőteljes korróziója (4. ábra). Ekkor kapta a BME Acélszerkezetek Tanszéke a feladatot, hogy állapítsa meg a lánclemezek korrózió okozta keresztmetszet-, illetve teherbírás-csökkenését, ami feltehetően az 1964-ben megindult olvasztó sózás hatására gyorsult fel.

A feladat lényege: a $12 \mathrm{db} 380 \mathrm{~mm}$ magas, $29 \mathrm{~mm}$ vastag, egymástól $29 \mathrm{~mm}$-re lévő, erősen korrodált, durva, korrózió-kráteres felületủ lánclemez-köteg minden egyes lánclemezén, a két-két csökkent keresztmetszetű láncköteg teherbírását meghatározó, leggyengébb keresztmetszetek megállapítása a horgonykamrákban legerősebben korrodált $2 \times 2 \times 2$ lemezköteg szakaszokon.

A méréshez a Tanszék egy olyan mérőmüszert fejlesztett ki, amely az előzőleg homokfúvással gondosan letisztított lemezekre szerelve és a lemezeken végighaladva, alkalmas az egyes lemezek maradék-keresztmetszeteinek megállapítására (5. ábra). A müszer egy nyitható, zárt keretre épült, amely a lemezekre felhúzható és amelyre hét mérőrugó-pár van felerősítve. A mérőrugó-párok egymás felé dőlnek úgy, hogy a rugók végén lévő, a lemezekre támaszkodó görgők közti távolság eredeti állapotban kb. $15 \mathrm{~mm}$. A mérőrugók tövére mindkét oldalon egy-egy nyúlásmérő ellenállás van felragasztva, amelyek segítéségével a mérőrugó-párok alakváltozása rekonstruálható. A mérőellenállások a mérési aszimmetria hatásának kiküszöbölésére teljes hídkapcsolásba vannak kötve [3].

A hét mérőrugó-páron elhelyezett mérőelemeket, mérőerősítőn keresztül egy személyi számítógépre kapcsoltuk, amely a mérőhelyeket egymásután letapogatta, a mérési eredményeket gyüjtötte és feldolgozta. A mérőmüszert minden felhelyezés előtt a méréstartománynak megfelelő vastagságú etalon-sorozattal hitelesítettük, és a hitelesítés során kapott eredményekből számított regressziós egyenes felhasználásával a PC a mérési eredményeket vastagságokként numerizálta. A méré- 


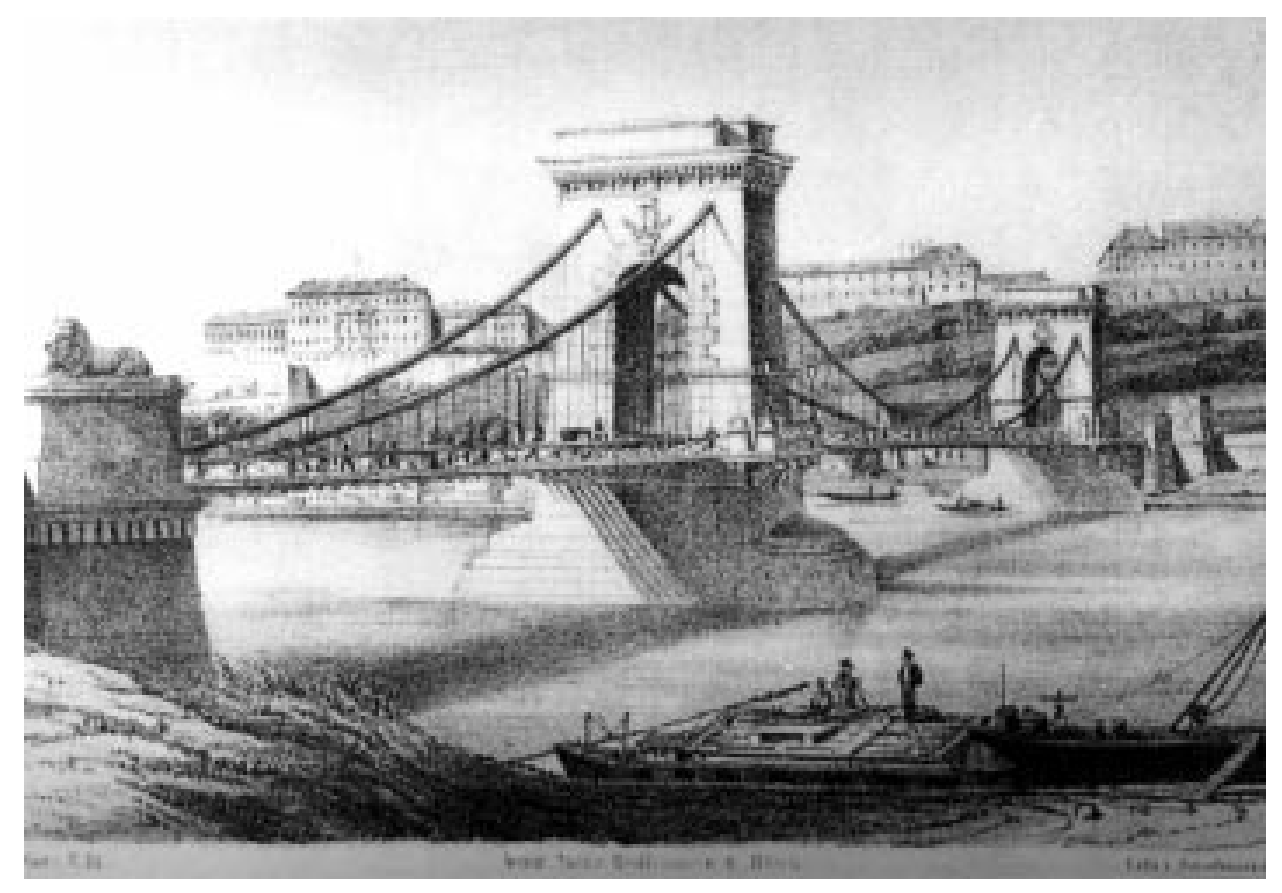

2. ábra. Az eredeti, 1849-es Lánchíd

3. ábra. Széchenyi-lánchíd az 1913-15-ös felújítás után

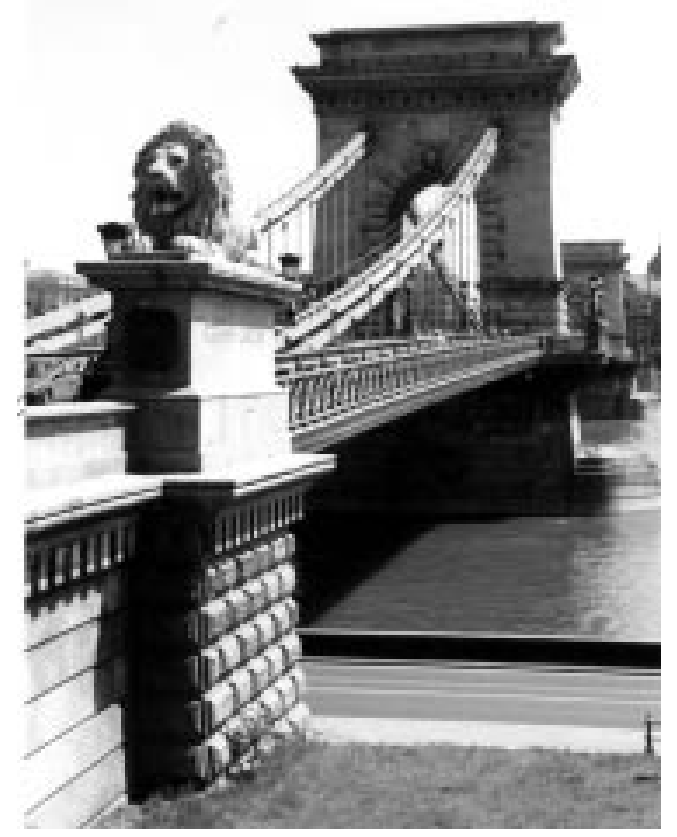



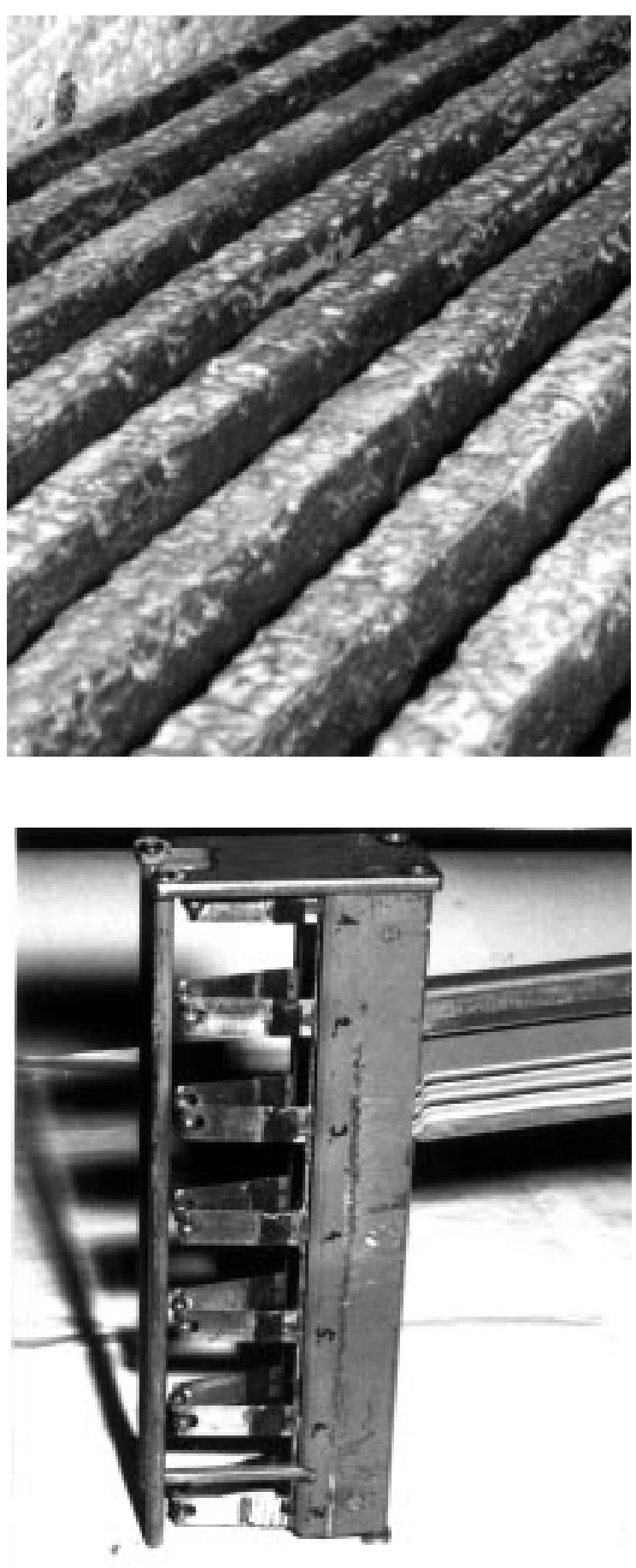

4. ábra. A Lánchíd erősen korrodált, homokfúvással letisztított lánclemezei a lánckamrában

5. ábra. A korrózió helyi mértékének megállapítására készített mérőmüszer 
sek az egyes lemezeken, a felületek állapotától függően, 5-25 cm-es közökben történtek. A számítógép a mért vastagságok, illetve a lemezenként mért leggyöngébb keresztmetszetek összege alapján az ellenőrző számítás alapjául szolgáló maradék keresztmetszetet, valamint a keresztmetszet-gyengítés \%-os mértékét kinyomtatta. A valódi maximális gyengítés ennél 1-2\%-kal nagyobb is lehet, mivel a mérésekkel nem feltétlenül sikerült a lemez leggyengébb pontjait felkeresni.

A $2 \times 2 \times 2 \times 12 \mathrm{db}$ lánclemeznek a lánckamrákba eső legerősebben korrodált $\approx$ 5-6 m hosszú lemezszakaszain felvett kb. 40000 mérési eredmény alapján az adódott, hogy a lemezkötegek leginkább gyengített keresztmetszete összességében a budai hídvégen a névleges keresztmetszet $91 \%$-a, a pesti hídvégen $96 \%$-a volt. A legerősebben korrodált lemez gyengítése elérte a $20 \%$-ot. Az eredmények, illetve a korábban említett okok alapján javasoltuk, hogy a lánclemezek hasznos keresztmetszetét az erőtani ellenőrzés során a névleges keresztmetszet 0,90-szeresével vegyék számításba.

Felhívtuk a figyelmet a korrózió elleni védelemre és a korrózió okainak megszüntetésére (a lánckamrák szigetelésének javítása), mert a korrózió további növekedése a híd használhatóságát veszélyeztetheti.

A hídon próbaterheléseket is végeztünk, amelyek során mértük a híd alakváltozását, a láncerőket, a függesztőerőket és a merevitőtartó feszültségeit. A mérési eredményeket számítógépes szimulációval kapott eredményekkel hasonlítottuk össze [4]. Az összehasonlítás azt mutatta, hogy a mért és számított erőjáték összhangban van és a hídszerkezet az elvégzett javítások után, megfelelő karbantartás esetén a Közlekedési Minisztérium által megállapított korlátozott terhek viselésére alkalmas.

Tudomásunk szerint a horgonykamrák nedvesség-mentesítését és a lánclemezek korrózió elleni megfelelő védelmét nem sikerült tökéletesen megoldani és a horgonykamrákban lévő lánclemezeken a korrózió ismét megjelent. Az ismét jelentkező korrózió okozta gyengítést mérésekkel kellene ellenőrizni, a korróziót kiváltó okokat meg kellene szüntetni, vagy legalább tovább kellene csökkenteni és a korrózió elleni védelmet fel kellene újítani. Ilyen intézkedés, valamint egyre sürübben végzendő állapotellenőrzés kedvező eredményei birtokában, folyamatos karbantartás mellett az 1913-15. évi átépítéstől számított 100 évig a személyautóés autóbusz-forgalom nagy valószínúséggel fenntartható, de legkésőbb 2015-ben, elsősorban az akkor 100 éves kort elérő láncok szempontjából, az autóbusz-forgalom fenntarthatóságát, véleményünk szerint, újra kell vizsgálni. 


\section{ERZSÉBET HÍD}

Budapest negyedik állandó hídja, mely építésének idején a világ legnagyobb nyílású lánchídja volt, Kherndl Antal számítása, Beke József és Gállik István tervei alapján 1903-ban került átadásra. Az 1945-ös felrobbantás után az 1964-ben befejeződött újjáépítés során Sávoly Pál tervei alapján kábelhídként épült meg, ortotrop pályalemezzel. A 6 sávos hídpálya alatt lévő, szögecselt merevítôtartó folytatólagos többtámaszú tartó. A középső két forgalmi sávban kezdetben villamos közlekedett, de az ortotrop lemez egyre gyakoribb meghibásodása miatt a villamosforgalmat a 2. metróvonal megnyitása után a hídról le kellett venni.

A Tanszék a szerelés során Gerber-tartóként kialakított merevítôtartó szerelési erőjátékának vizsgálatára modellkísérletet végzett (6. ábra). Az 1 : 50 léptékü kis-

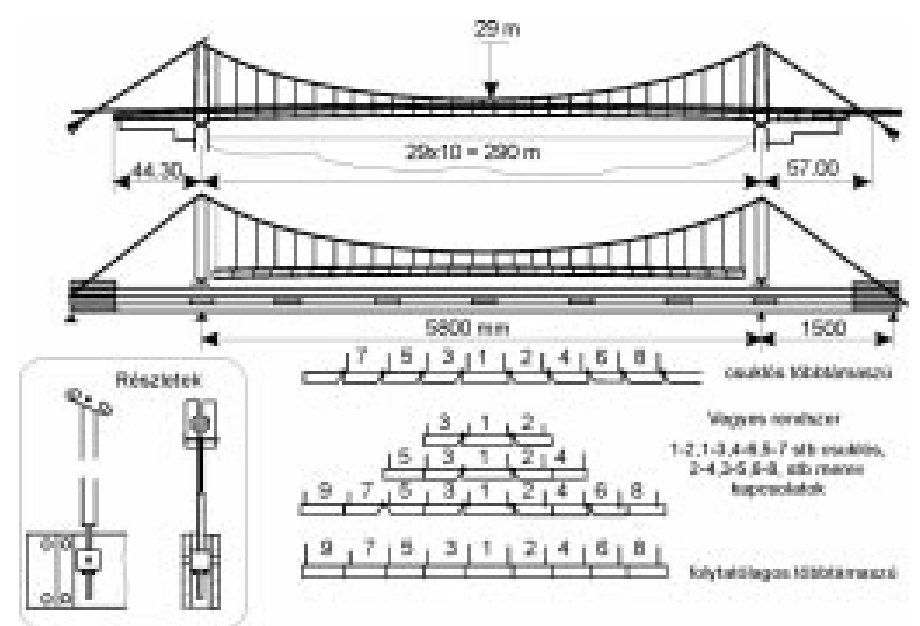

6. ábra. Az Erzsébet híd és 1 : 50 léptékű statikai modelljének fő méretei, valamint a merevítőtartó modellkísérlet során vizsgált szerelési változatai

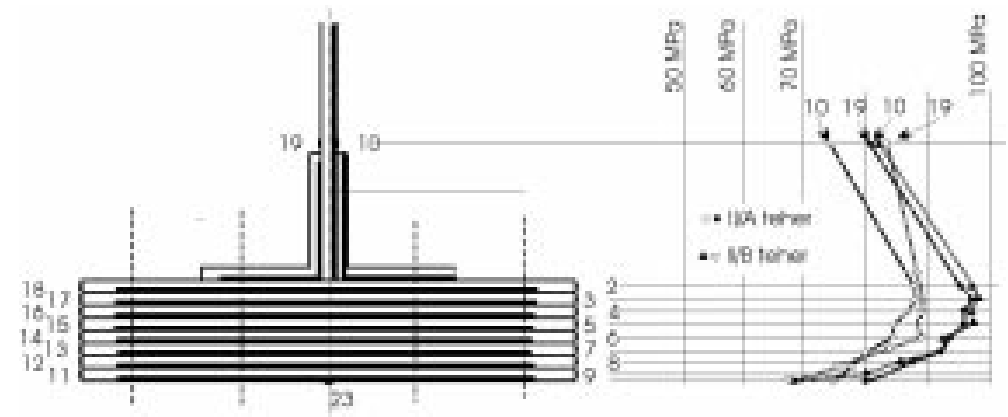

7. ábra. Az Erzsébet híd merevítőtartójának alsó övében a támasz felett az övlemezek élein mért feszültségek 
mintán a különböző szerelési fázisokban, illetve szerelési változatok esetében mértük a szerkezet alakváltozását és a függesztőkábelekben keletkező erőket [5]. Erre elsősorban amiatt volt szükség, hogy ne kelljen megvárni a Gerber-tartóként kialakított merevítőgerendák csuklóinak zárásához szükséges szögecselési munka elvégzésével (mintegy 200000 szögecs) a merevítőtartó teljes hosszon való beszerelését.

Az elkészült híd próbaterhelésénél a merevítôtartó pilon alatti támaszánál lévő 8-övlemezes keresztmetszeténél nyúlásmérő ellenállásokkal ellenőriztük a keresztmetszet feszültségeloszlását, különös tekintettel a $8 \times 20 \mathrm{~mm}$ vastag övlemezköteg erőtani viselkedésére. A mérési eredmények igazolták, hogy ilyen vastag, szögecselt lemezkapcsolat nem tekinthető teljesen merevnek és az övlemezekre már nem érvényes a Bernoulli-Navier hipotézis (7. ábra).

\section{SZABADSÁG HÍD (FŐVÁM TÉRI FERENCZ JÓZSEF HÍD)}

Budapest harmadik állandó hídja a Fővám téri Ferencz József híd, az első magyar tervek (Feketeházy János - Nagy Virgil - Seefehlner Gyula) alapján, magyar kivitelezésben (MÁV Gépgyár) magyar Martin-acél anyagból épült híd. Az 1894-ben megkezdett építési munkák után, az alapozással együtt 2 éven belül (!) 1896-ban került átadásra.

A szecessziós stílusban épült híd több szempontból rászolgál arra, hogy az egyik legjelentősebb magyar müszaki emlékként, illetve müemlékként tartsuk nyilván. Ezeket a szempontokat, valamint a hídra vonatkozó legfontosabb múszaki adatokat a Feketeházy János születésnapjának 150. évfordulója alkalmából 1992. május 12-én tartott tudományos emlékülésen ismertettük [6]. A Gerber-fötartós hidat a szakirodalom a Gerber-hidak egyik legszebbjeként említi.

1945-ben a középső, befüggesztett tartót robbantották fel. 1945 telén a középső részt uszályokra szerelt provizóriummal egészítették ki, amit a jégzajlás elsodort. 1946 februárjáig, a félállandó Kossuth híd megnyitásáig Budapest közúti híd nélkül maradt.

Mivel a budapesti hidak közül, háborús sérülésekkel ugyan, de ennek a hídnak maradt viszonylag épen a legnagyobb része, 1946 tavaszán először ennek a hídnak az újjáépítése kezdődött meg. Az újjáépített hídon a forgalmat 1946. augusztus 20án nyitották meg újra. Az újjáépítés során a háborús sérülések legnagyobb részének javítása, tekintettel a rendelkezésre álló rendkívül rövid időre, hegesztéssel történt - mint az később kiderült - a helyenként igen magas foszfortartalmú tartószerkezeten. Ugyancsak hegesztéssel történt a kihajlással szembeni kedvezőbb viselkedés érdekében a nyomott oszlopok és néhány húzott-nyomott rácsrúd hevede- 
rezése. A háborús sérülések miatt kiesett oszlopok pótlását a csatlakozó csomópontok szétnyomása után, vagy egyes helyeken anélkül végezték. A teljes egészében újonnan épült befüggesztett részen és a konzolok egy részén a pályatartók más hidak kiemelt roncsanyagából, hegesztett toldásokkal, a meglévő szögecslyukak behegesztésével készültek. Az ilyen, mai szemmel nézve teljesen szakszerütlen javításokat, amelyek a főtartó háborús sérüléseinek helyén is igen nagy számban fordulnak elö, a fáradással kapcsolatos káros hatások ismeretének hiánya, a rendkívül szoros határidő és a politikai nyomás indokolta.

A problémát fokozta az a tény is, hogy az 1896-os szerkezet egyes megoldásai már eleve magukban hordozták a későbbi hibaforrásokat (szük hézagok, építés után hozzáférhetetlen és javíthatatlan helyek), amelyeknek kedvezőtlen hatása nagy valószínüséggel az 1964-ben megindult olvasztó útsózás hatására gyorsult fel.

Az 1965-1968 között végrehajtott, első részletes felülvizsgálatnál, illetve mázolásnál állapították meg, hogy az oszlopok kettős gerince közötti 24, illetve 42 mm széles hézagokban, ahol még két egymással szembenálló szögecsfej is elhelyezkedik, a felületek tisztítása és kifogástalan újramázolása szinte lehetetlen. Ekkor azonban még jelentős korróziós kárt nem tapasztaltak.

1975 után vált láthatóvá, hogy a háború során épen maradt pesti, eredeti ellensúly-szekrény tartói erősen korrodálódtak, és féló volt, hogy a mintegy 600 tonna tömegủ ellensúly leszakad. Az 1978-ban megkezdett felújítás elsősorban az ellensúly-szekrények cseréjét volt hivatott biztosítani, de az emiatt szükséges hídlezárás miatt ekkor került sor a kocsipálya alatti szigeteletlen pályalemez cseréjére is. Nem történt meg ekkor a gyalogjáró alatti lemezek cseréje, amelyen a fötartó oszlopai és rácsrúdjai átbújnak. Az oszlopok gyalogjáró által takart részének ellenőrzésére csak 1985-ben került sor, amikor a gyalogjárók cseréjét, a főtartók javítását és mázolását is elvégezték [7].

A gyalogjáró bontása során derült ki, hogy a lemez által takart, sok helyen az aszfaltozás miatt be is szükült, mintegy $15-20 \mathrm{~cm}$-es szakaszon az oszlopok, elsősorban az eredeti, 1896-os hídrészeken (oldalnyílások) a keresztmetszet korrózió okozta gyengítése 10-60 \% között van. Az 1946-ban újonnan épült befüggesztett tartón és a konzol-szakaszokon a gyengítés általában nem érte el a $10 \%$-ot. A $10 \%$-nál erősebben korrodált oszlopokat a teljes rúderő felvételére alkalmas, a híd összképét nem zavaró erősítéssel látták el, amelyet az eredeti szerkezethez illesztőcsavarokkal kapcsoltak.

A járdalameznek a déli fôtartó budai parti nyílásában lévő 6-6' oszlop melletti bontása közben az erősen korrodált oszlop hirtelen megroppant, kb. $15 \mathrm{~mm}$-rel megrövidült, felső része déli irányban kb. $35 \mathrm{~mm}$-rel eltolódott (8. ábra), de a két oszlopvég továbbra is egymásra felült. Az így kialakult veszélyhelyzetben a híd teljes lezárásával egy időben, a további mozgás megakadályozására a két oszlop- 


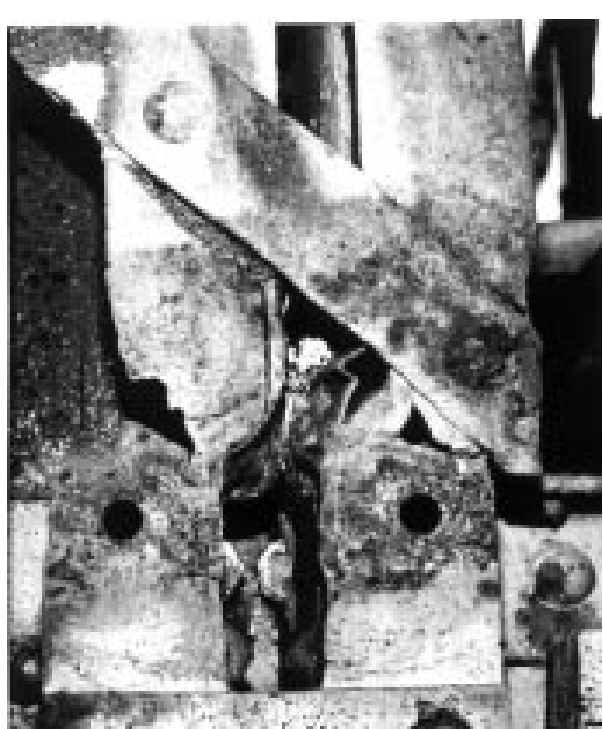

8. ábra. A Szabadság híd déli főtartóján a budai nyílásban lévő 6-6' rúd megroppant keresztmetszete a járdán való áttörés helyén, letisztítás után

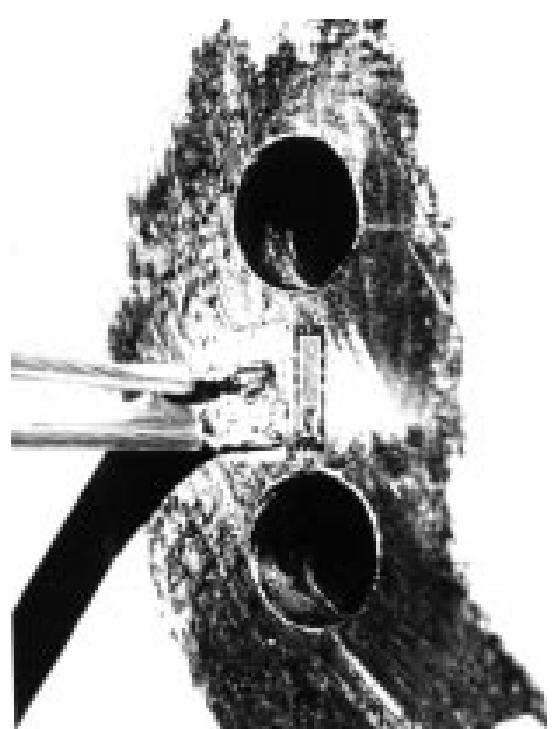

9. ábra. A 6-6' rúdban a megroppanás után maradt rúderő megállapítására a rúdelemekre ragasztott egyik nyúlásmérő ellenállás, két végén a feszültség felszabadítására fúrt lyukak

vég egymáshoz rögzítése történt meg. A helyreállítás megkezdéséhez első lépésként a sérült oszlopban és annak környezetében lévő rudakban meglévő erőt kellett megállapítani, és azokat az önsúlyból számított rúderőkkel össze kellett hasonlítani. A rekonstrukciót irányító UVATERV ekkor bízta meg a Tanszéket a kérdéses rúderők megállapításával, a javítási technológia kidolgozásában való közremúködéssel, a javítás során alkalmazandó mérő- és regisztráló-rendszer összeállításával, a mérések előkészítésével, a sérült 6-6' oszlop helyreállításának levezetésével, és végül a forgalomba helyezést megelőző próbaterhelés megtervezésével, lebonyolításának irányításával és a mérési eredmények alapján a forgalomba-helyezésre vonatkozó javaslat előkészítésével.

A vizsgált rudakban az önsúlyból meglévő rúderő meghatározására a részleges trepanációs módszert alkalmaztuk. Ehhez a vizsgált rudak minden egyes elemére (4 gerinc +8 szögacél) a rúd különböző magasságában egy-egy 10 mm bázisú nyúlásmérő ellenállást ragasztottunk (9. ábra). A nyúlásmérő ellenállások két végéhez több lépésben $\varnothing 12 \mathrm{~mm}$-es lyukakat fúrtunk, felszabadítva ezzel a két lyuk közötti szakaszon lévő feszültségeket. A mért feszültségek és a keresztmetszet alapulvételével számítani tudtuk a rúderőket, amelyeket a statikai számítás alapján kapott erőkkel hasonlítottunk össze. Eszerint a 6-6' oszlopban az önsúlyból számított $-2200 \mathrm{kN}$ erő helyett csak $-871 \mathrm{kN}$ tényleges erő volt mérhető, amely úgy adódott, 
hogy a gerincekben nagy nyomófeszültséget, míg az övszögacélokban, a szakaszosan felhegesztett erősítő borda és a felhegesztett hevederlemezek hegesztés okozta sajátfeszültségei miatt kisebb húzófeszültségeket mértünk. A szomszédos rudakban mért és számított rúderők közt az eltérés nem volt jelentős, kivéve a 9-9' oszlopot, amelyet az 1946-os felújításnál, mint az később kiderült, a csatlakozó csomópontok szétnyomása nélkül állítottak helyre, s amelyen ezért gyakorlatilag feszültségmentes állapotot $(-83 \mathrm{kN})$ kaptunk.

A rúderők ismeretében került sor a helyreállítási technológia kidolgozására. Ennek megfelelően a 6-6' oszlop alsó és felső övhöz való csatlakozásánál a rúd két oldalára egy-egy átmenő övlemezt csavaroztak. Az alsó övnél elhelyezett átmenő övlemez alá a félszelvényeknek megfelelő szélességü övlemezeket helyeztek el, amelyekhez később, hegesztéssel toldva, a javítás helye egy-egy hevederrel áthidalható. Az alsó és felső övlemezekre hegesztették fel a kiváltó rudazat elemeit, amelyek csatlakozó végeinél került elhelyezésre a rúd szétnyomására alkalmas 4 db 1000 kN-os, párhuzamosan kapcsolt, hidraulikus munkahenger. A 6-6' oszlop és a szomszédos rudak elemeire az eróátadás megfigyeléséhez nyúlásmérő ellenállásokat ragasztottunk.

A sérült rúd javításának folyamatos és részletes megfigyelése érdekében a munkahengerek nyomóerejét, a 6-6' oszlop és a szomszédos rudak elemein mért feszültségeket és az ezekből számított rúderőket számítógéppel gyüjtöttük, és az eredményeket a PC monitorán megjelenítettük, majd kinyomtattuk és a 6-6' oszlop rúderejének változását a munkahengerek által teljesített nyomóerő függvényében folyamatosan ábrázoltuk.

A rúd helyreállítása során, a munkahengerek minimális erőfelvételét követően először a két rúdvég közötti ideiglenes kapcsolatot kellett oldani. Ezután a nyomóerőt 200 kN-os lépcsőkben 1000 kN-ra növeltük, folyamatosan követve a 6-6' oszlopban és a szomszédos rudakban keletkező erőket. Figyelembe véve a 6-6' oszlop és a szomszédos rudak kismértékủ együttdolgozását, kb. 1000 kN erőnél volt várható, hogy a 6-6' oszlopban az elözetes méréssel megállapított-871kN-os rúderőt elérjük (10. ábra).

Ekkor kezdtük meg a sérült keresztmetszet átvágását, a szélekről szimmetrikusan indulva, több lépésben. Az átvágás alatt mérhető nyomóerő-változást vagy mozgást nem tapasztaltunk. A munkahengerek nyomóerejének 2000 kN-ig való növelése során a 6-6' oszlop rúderejében számottevő változást nem mértünk. Ennél az erőnél végeztük el $2 \times 2 \mathrm{db} 50 \mathrm{kN}-o \mathrm{~s}, 10 \mathrm{~mm}$ lökethosszúságú munkahengerrel, több lépésben a vízszintes irányban $35 \mathrm{~mm}$-rel elmozdult felső rúdvég helyretolását. Ekkor az eredeti hálózati állapotban rögzítettük a két rúdvég helyzetét.

A következő munkanapon történt meg a 200 mm magas, előkészített közdarab elhelyezéséhez a sérült rúdrészek kivágása és a vágási felületek gondos lecsiszolása. A közdarab elhelyezésének megkönnyítésére a nyomóerőt 2800 kN-ra növel- 


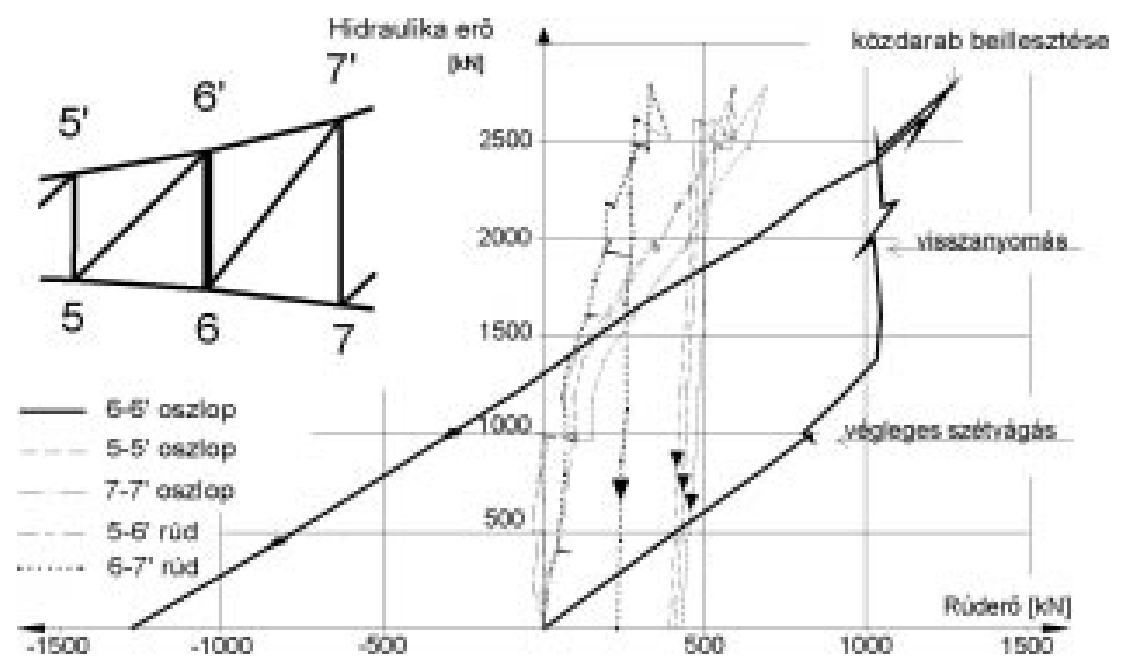

10. ábra. A rúd helyreállítása során felvett hidraulikus nyomóerő és a mért tényleges rúderő diagramja a fő munkafázisok feltüntetésével

tük. A harmadik napon történt meg az alsó rúdfélre felszerelt övlemezek toldása, az így kialakuló hevederekkel, amelyek a teljes, eredeti, terv szerinti rúderő felvételére alkalmasak, valamint a sérült és javított rúdrészek illesztőcsavaros kapcsolattal történő áthidalása.

A munkahengerek tehermentesítésekor a 6-6' oszlop alsó és felső rúddarabján feszültségméréssel ellenőriztük a keletkező erőket. A 2620 kN-os nyomóerő megszüntetésekor a felső rúdvégen nyúlásmérő ellenállásokkal -2457kN, az alsó rúdvégen Pfender-féle mozgatható nyúlásmérővel $-2815 \mathrm{kN}$ nyomóerőt mértünk. A teljes munkafolyamat mérési eredményei az 10. ábrán jól követhetők.

A helyreállítás befejezése után a 6-6' oszlop és 9-9' oszlop viselkedését próbaterheléssel ellenőriztük és azt tapasztaltuk, hogy mindkét tényleges rúderő a számítottnál kb. $20 \%$-kal alacsonyabb, ami a többtámaszú eróátvitellel, valamint a főtartó és hossztartók kismértékủ együttdolgozásával magyarázható.

A híd felújításának teljes befejezése után próbaterheléssel ellenőriztük a híd viselkedését. A mért és számított alakváltozások és feszültségek egyezése megnyugtató volt. Az 1987 júliusában történt próbaterhelést reggel 6 órakor kezdtük és délben 12 óra körül fejeztük be. Közben a hőmérsékletváltozás kedvezőtlen hatásának kiküszöbölésére minden órában tehermentes állapotot mértünk. A 6 órai kezdő és a 12 órai befejező, terheletlen állapotnál mért alak között érthetően igen jelentős eltérést tapasztaltunk. Ennek a mérési eredménynek az ellenőrzésére számítást végeztünk feltételezve, hogy a felső öv rúdjai $10{ }^{\circ} \mathrm{C}-k a l$, a rácsok és oszlopok pedig 

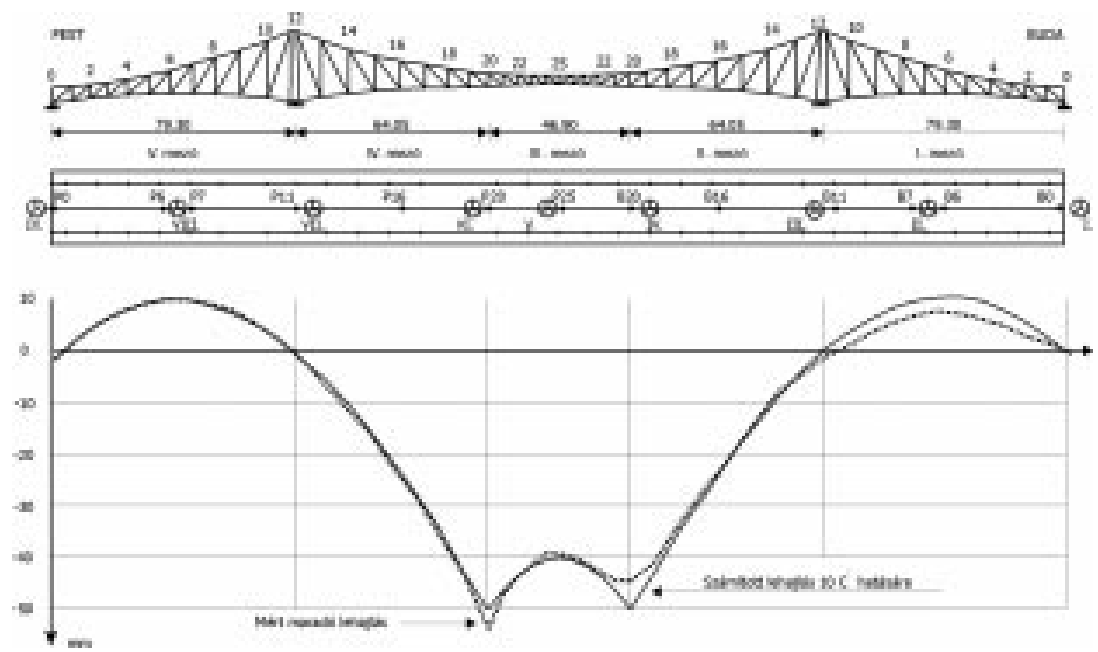

11. ábra. A Szabadság híd 1986-os újra forgalomba-helyezése előtt tartott próbaterhelés alakváltozási ábrái és a tehermentesített állapotban reggel 6 óra és déli 12 óra között mért alak különbségének a $10{ }^{\circ} \mathrm{C}$ egyenlőtlen hőmérsékletváltozásból számított alakkal való összehasonlítása

$5{ }^{\circ} \mathrm{C}$-kal melegedtek fel jobban, mint az alsó öv rúdjai. Az így számított alak a mérttel szinte tökéletesen megegyezett (11. ábra).

Tekintettel a híd legnagyobb részének 100 éves korára, a nem jól hegeszthető acélminőségre, a háborús sérülések és felrobbantás miatt kialakult meg nem állapítható nagyságú belső feszültségekre, az 1946-os újjáépítés során alkalmazott, ma már szakszerütlennek és meg nem engedhetőnek tekintett, hegesztéssel végrehajtott erősítésekre, az előrehaladott korrózióra, a fáradási veszély csökkentése érdekében javasoltuk a tömegközlekedésnek a hídról való letiltását és csak a személyautó és gyalogosforgalom fenntartását. Az autóbuszforgalom levétele meg is történt, de a villamosforgalom kiváltása a 4-es Metró építésének eltolódása miatt eddig nem volt megoldható.

Az újabb hídszabályzati és Eurocode előírásoknak megfelelő ellenőrzés elsősorban fáradás szempontjából a fötartó egyes elemeinek megerősítését tette szükségessé. Mivel a főhatóság a megerősítés biztonságos végrehajtásához szükséges forgalomkorlátozást nem engedélyezte, az erősítési munka elodázhatósága érdekében ellenőriztük néhány kérdéses, húzott rúdnál egy hétköznapon lebonyolódó forgalom hatására kialakuló feszültségspektrum maximális értékeit [8]. Ehhez a mért, fáradás szempontjából mértékadó keresztmetszetekben, a keresztirányú varratok környezetében, a négy övszögacélon mértük a forgalom alatt keletkező feszültségeket, számítottuk a normál- és hajlító feszültség-komponenseket, és ezek 5 perces időtartamra meghatározott szélső értékei közötti különbséget fogadtuk el 
tényleges feszültséglengésként. Mivel az így kapott értékek 28 MPa-nál kisebbek, vagy azt csak igen ritkán és igen kis mértékben lépték túl, javasoltuk az erősítésnek egy olyan időpontra való eltolását, amikor az megfelelő forgalomkorlátozással biztonságosan elvégezhető. A villamosforgalom levétele esetén az erősítésre nincs szükség.

\section{DÉLI ÖSSZEKÖTŐ VASÚTI DUNA-HÍD}

Az 1947-48-ban Korányi Imre tervei alapján újjáépült, ma a jobb vágányban fekvő híd utolsó felülvizsgálatára 1989-ben került sor. Mivel a híd hossztartóinál, a hossztartó-megszakítás környezetében fáradt töréseket is találtak, a MÁV kérésére foglakoznunk kellett a híd, ezen belül a főtartó és pályatartók további élettartamának megállapítására vonatkozó becsléssel is [9].

A vizsgálat során első lépésként a hossztartók mért és számított viselkedését hasonlítottuk össze vonathatásábrák segítségével (12. ábra). A kedvező eredmény birtokában ezt követte egy olyan forgalom alatti méréssorozat, amelynek során a fötartó és hossztartók jellemző pontjaiban mértük a feszültségeket, és a mérési eredményeket direktírón és mérőmagnetofonon rögzítettük. A forgalom alatti mérés 100 egymás után áthaladó vonat hatásának a mérésére terjedt ki. A mérési eredményeket kiegészítettük azzal a mérési adattal, amelyet a többi méréssel egy időben, a híd előtti szakaszon, két keresztalj között, az egyik sínszál alsó felületére felragasztott nyúlásméró ellenállás segítségével vettünk fel (13. ábra).

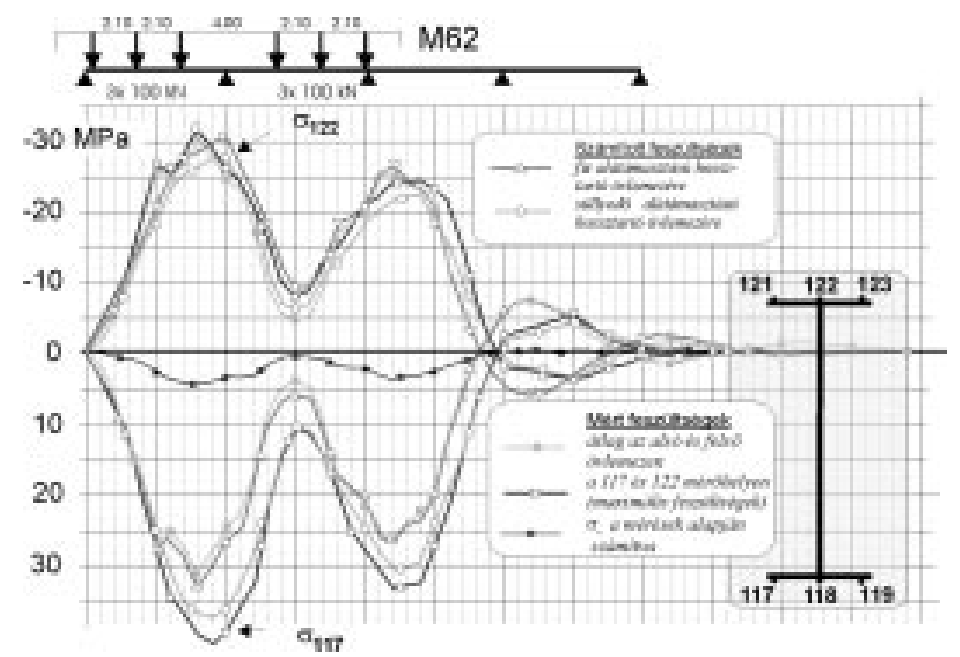

12. ábra. A Déli Összekötő Vasúti Duna-híd hossztartóján mért és számított vonathatásábrák összehasonlítása 

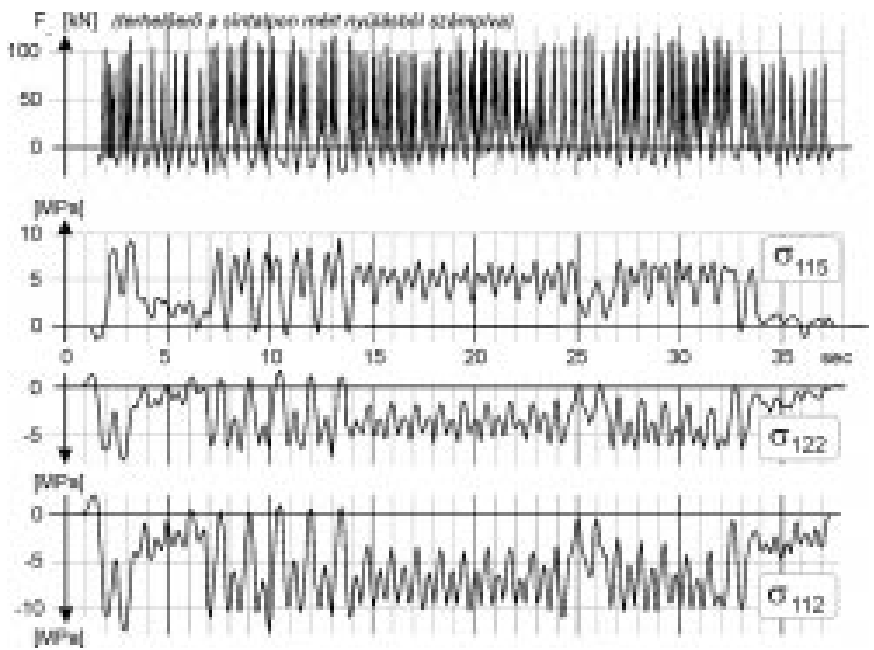

13. ábra. A terhelő vonatok áthaladása közben a síntalpon és a hossztartó különböző pontjaiban mért nyúlások, illetve az azokból számított feszültségek

A kapott mérési eredmény hitelesítéséhez minden áthaladó vonatnál feljegyeztük a vontatómozdony típusát. A mozdony névleges tengelysúly és tengelytávolság adataiból, a síntalpon mért feszültségek felhasználásával a vonatok összeállítása mind a tengelysúlyok, mind a tengelytávolságok vonatkozásában jól becsülhető volt.

A 100-vonatos mérés adatainak a „reservoir-módszerrel” végzett számítógépi értékelésével meghatároztuk a szerkezet mért pontjaiban a tényleges teher hatására keletkező feszültséglengések nagyságait és ezek célszerúen megválasztott határok közti osztályozását. Az így kapott eredményeket a MÁV 1987-es és 1988-as forgalmi adatainak megfelelően extrapoláltuk, és az adatokat személyvonatokra, tehervonatokra és gépmenetekre csoportosítottuk.

Feltételezve, hogy a fárasztó igénybevételek ily módon meghatározott gyakorisága a híd megelőző és ezt követő használata során lényegesen nem tér el, az alábbi módon becsülni tudtuk a szerkezet biztonságát, illetve várható élettartamát. Ennek megállapításához a Palmgren-Miner-féle halmozódó károsodás elméletét használtuk fel. Ennek lényege, hogy valamely $\mathrm{N}_{\mathrm{i}}$ élettartamhoz tartozó $\Delta \sigma_{\mathrm{i}}$ igénybevétel (feszültséglengés) $n_{i}$ számú elviselése a szerkezetet $n_{i} / N_{i}$ mértékben károsítja. Figyelembe véve a szerkezet előéletét, egy vizsgált időpontban a szerkezet károsodásának mértéke:

$$
\frac{1}{\bar{n}}=\sum \frac{n_{i}}{N_{i}},
$$


illetve biztonsága:

$$
\bar{n}=\frac{1}{\sum \frac{n_{i}}{N_{i}}} .
$$

A szerkezet törése akkor következik be, ha a károsodások összege eléri az 1,0 értéket:

$$
\sum \frac{n_{i}}{N_{i}}=1
$$

A szerkezetre érvényes, illetve elöírt Wöhler-görbe egyenlete lg-lg rendszerben egyenessel közelítve a következő alakban írható:

$$
N=\frac{C}{\Delta \sigma^{m}}
$$

ahol $\mathrm{N}$ a $\Delta \sigma$ feszültséglengéshez tartozó ismétlési szám (élettartam), $\mathrm{C}$ egy állandó, amelynek értéke az egyes fáradási fokozatokra meghatározott vagy előírt $\Delta \sigma_{\mathrm{f}, \text { eng }}-\mathrm{N}_{\sigma_{f, \text { eng }}}$ értékpárok ismeretében a

$$
C=N_{\sigma_{f, \text { eng }}} \cdot \Delta \sigma_{f, \text { eng }}^{m}
$$

képlettel számítható.

A Wöhler-görbe egyenletét (4) beírva az (1)-(3) összefüggésekbe a szerkezet károsodásának mértéke, illetve biztonsága és várható élettartama megbecsülhető, ha ismerjük a szerkezet igénybevételének történetét. Az m értékét a szakirodalomban hegesztett szerkezeteknél $m=3$, szögecselt szerkezeteknél $m=4$ értékkel adják meg.

A számítások során a magyar előírások szerint a szabályzatban megadott üzemi teherre vagy a tényleges vonatok alapján összeállított típusvonatok adataival végzett számításokra, illetve ahogy azt mi tettük, a tényleges forgalomban felvett mérések feldolgozott eredményeire lehet támaszkodni.

A Déli Összekötő Vasúti Duna-híd főtartói károsodásának számításánál a 100vonatos mérés fajlagos terhei alapján számított rúdfeszültségeket használtuk fel, amelyeket az egyenlőtlen feszültségeloszlás miatt 1,2-del, a dinamikus hatás miatt 1,05-dal, valamint a teljes és hasznos keresztmetszet arányát figyelembe véve 1,205-del, összesen tehát 1,518-del megszoroztunk. A károsodás mértékét 50 évre extrapolálva számítottuk a $\Delta \sigma_{\text {f,eng }}=100 \mathrm{Mpa}, \mathrm{N}_{\sigma_{f, \text { eng }}}=2,10^{6}$ és $\mathrm{m}=4$ értékekkel jellemzett Wöhler-görbe alapján. 50 éves korra a fötartók károsodásának mér- 
téke $1 / \mathrm{n}=0,0136$, a biztonság $\mathrm{n}=73,5$, ami a 100 éves élettartam esetén is még igen kedvező marad, más szóval a főtartók fáradásával nem kell számolnunk.

A hossztartók károsodásának mértékét ugyancsak 50 évre extrapoláltuk a $\Delta \sigma_{\text {f,eng }}=100,90$ és $80 \mathrm{Mpa}, \mathrm{N}_{\sigma_{f \text { eng }}}=2 \cdot 10^{6}$ és $\mathrm{m}=4$ értékekkel jellemzett Wöhlergörbék alapján. Az alsó és felsó ôvilemez közepén, a két szögecssor között mért feszültséglengéseket a keresztirányú feszültségváltozás miatt 1,2-del, a szögecslyukaknál keletkező feszültségcsúcsok miatt 1,25-dal, összesen tehát 1,5-del szorozva vettük figyelembe. Az egyes mérőhelyeken mért feszültséglengések sztochasztikus feldolgozása alapján a 100-vonatos mérés adatainak felhasználásával a jellemző mérőhelyeken az 50 éves üzemre vonatkozó eredmények a következők voltak:

$\Delta \sigma_{\text {f,eng }}=100 \mathrm{MPa}$ érték esetén

a károsodás $1 / \mathrm{n}=0,476$,

$\Delta \sigma_{\mathrm{f}, \text { eng }}=90 \mathrm{MPa}$ csökkentett érték esetén

$\Delta \sigma_{\mathrm{f}, \text { eng }}=80 \mathrm{MPa}$ esetén a károsodás $1 / \mathrm{n}=0,726, \quad$ a biztonság $\mathrm{n}=1,38$;

a károsodás $1 / \mathrm{n}=1,163, \quad$ a biztonság $\mathrm{n}=0,86$.

Figyelembe véve, hogy a 100-vonatos mérések a többtámaszú hossztartó első, fixen bekötött mezejében és nem a hossztartó-megszakítás bizonytalanul megtámasztott mezejében történtek, ahol egyébként fáradt törések már elő is fordultak, indokoltnak látszik a $\Delta \sigma_{\text {f.eng }}=80 \mathrm{MPa}$ értékből kiindulni, és a számítások alapján a nagyobb forgalmú vasúti hidaknál a hossztartók várható élettartamát 50 évre becsülni.

A Déli Összekötő Vasúti Duna-híd 40 évi használat után kicserélt két hossztartójával laboratóriumi (statikus és fárasztó) vizsgálatokat is végeztünk [10]. Az egyik hossztartó jellemző pontjainál (zavartalan helyek, meglévő szögecslyukak helye, zavartalan helyről kivett pálcák most fúrt szögecslyukakkal) kivágott próbapálcákkal statikus szakító és húzó-fárasztó vizsgálatokat valamint a szögecslyukak környékén és attól távolabbi pontokon kivágott Charpy-próbatestekkel ütöhajlító vizsgálatokat végeztünk (14. ábra). A másik $l=6305 \mathrm{~mm}$-es hossztartót $1: 1$ állapotban, két koncentrált erővel terhelve, kéttámaszú tartóként fárasztottuk (15. ábra).

A statikus vizsgálatok azt mutatták hogy a hossztartók anyaga az A 37 minőségnek, a szögecslyukak környékéből kivett próbapálcákon mért fajlagos ütőmunka kivételével megfelel. Az alacsony ütőmunka oka a szögecslyukak környékén fellépő alakváltozásos öregedés.

Az alapanyag fárasztási vizsgálatok gerinclemezből és övlemezekből kivett zavartalan (A), meglévő szögecslyukakkal gyengített (B),valamint zavartalan próbatestbe utólag fúrt szögecslyukkal készült próbatestekkel (C) történtek. Az eredmények: 

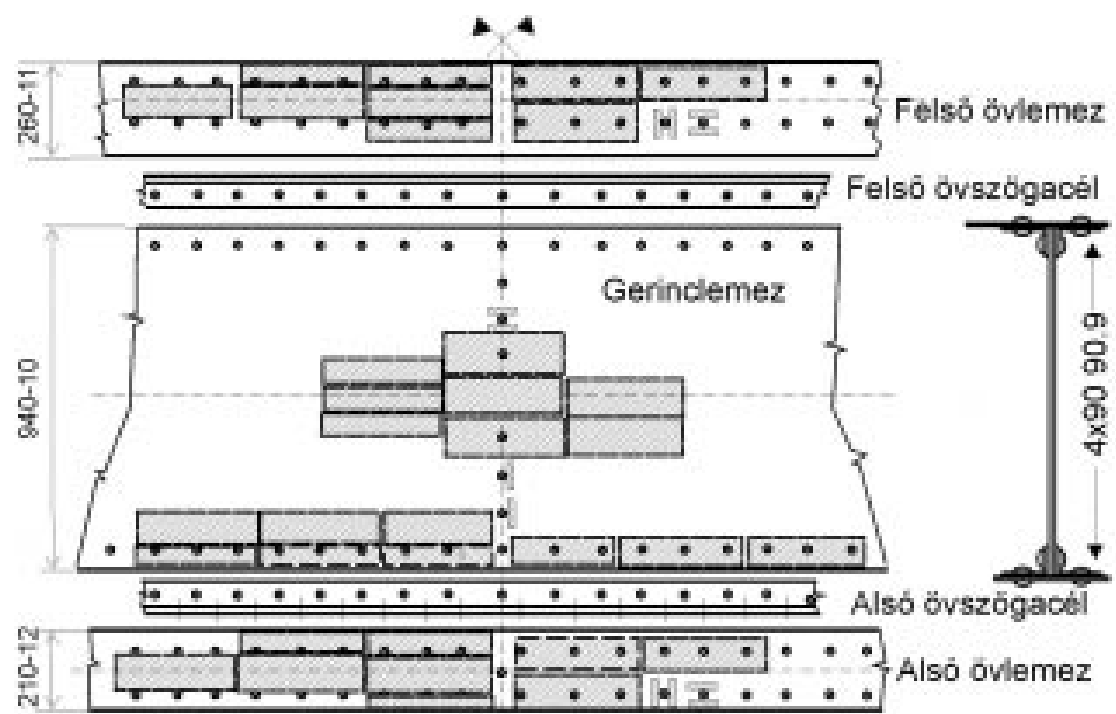

14. ábra. A Déli Összekötő Vasúti Duna-híd egyik kicserélt hossztartójának anyagvizsgálatához a próbatestek kivágási terve

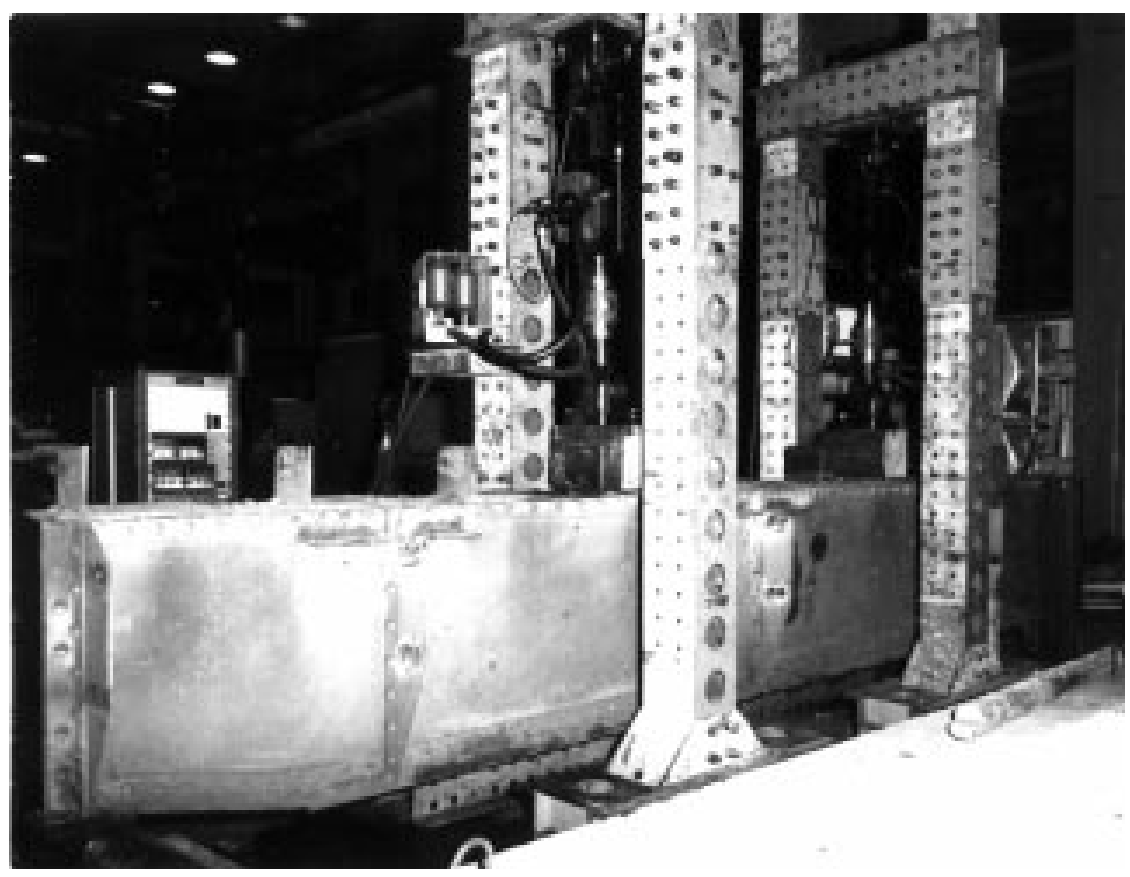

15. ábra. A másik hossztartó $1: 1$ laboratóriumi fárasztó kísérlete két terhelő erővel 
$\mathrm{Az}$ „A” jelű próbák átlagos kifáradási határa

a „B” jelü próbák eredményei

a „C" jelüeké pedig
$200 \mathrm{MPa} \pm 5 \%$, 100-130 MPa között szórtak, 126-154 MPa között voltak.

A teljes hossztartó lépcsős fárasztási vizsgálatánál $2 \times 100 \mathrm{kN}$ alapteherrel indultunk és ezt $10 \mathrm{kN}$-os lépcsőkben $10^{5}$, illetve $2 \times 10^{5}$ ismétlési számokkal a munkahengerek felső kapacitásáig $240 \mathrm{kN}$-ig növeltük. Ez $2 \mathrm{~m}$ tengelytávolságban lévő egyenként $480 \mathrm{kN}$ tengelynyomásnak felel meg. A fárasztott hossztartón fáradási jelenséget nem tapasztaltunk. Az egyetlen fárasztási vizsgálat eredményének feldolgozása alapján a $\Delta \sigma_{\text {f.eng }}=100 \mathrm{MPa}, \mathrm{m}=4$ és a feszültségeloszlás egyenlőtlenségét jellemző $\mathrm{c}_{1}=1,5$ mint kiinduló paraméterek a vasúti hidak hossztartóinak vizsgálatánál reálisnak tünnek, de a paraméterek kedvezőtlenebb értékeinél a $\Delta \sigma_{\text {f.eng }}$ értékét csökkenteni kell.

Konklúzióként kimondhatjuk, hogy a Déli Összekötő Vasúti Duna-híd fôtartójának vonatkozásában fáradási meghibásodás nem várható, de a hossztartóknál 50 év után, kedvezőtlen körülmények között a fáradás előfordulhat, ezért 50 év után a hossztartók állapotát fokozott gonddal kell ellenőrizni, és célszerű felkészülni a hossztartók esetleg szükséges cseréjére.

\section{PETŐFI HÍD}

Az 1945-ben felrobbantott, Álgyay-Huber Pál által tervezett háromnyílású, felsőpályás, rácsos híd megnyitására 1937-ben került sor. 1952-ben a hidat a pálya szélesítésével és a pálya emelkedésének csökkentésével, egyébként csak kisebb változtatásokkal építették újjá.

Az 1978-80 között végzett rekonstrukció során a pályalemezt kicserélték. A bontás alatt a sarukat nem védték megfelelően, így a pesti hídfónél a lehulló törmelék miatt a saruk nem tudtak a hídfő felé elmozdulni, és ezért a szerkezetről leszakadtak. Ezt a hibát viszonylag egyszerüen lehetett javítani. Ugyanekkor vették azt is észre, hogy a budai mederpilléren lévő 6 lecsapott oldalú hengerrel, a hengerek között 20 mm hézaggal kialakított 4 mozgósaru leblokkolt, és így a két mederpillér a továbbiakban a hőmozgást ingaoszlopként vette fel. A két pilléren a hőmozgás miatt fellépő kb. $30 \mathrm{~mm}$-es, egymással ellentétes mozgás a szerkezet biztonságát nem zavarta. A folyamatosan mért pillérmozgások az idők folyamán eltérést nem mutattak, de a közbenső mozgósaru leblokkolásának megszüntetése feltétlenül szükséges volt.

A hiba kiküszöbölésére a négy saru cseréjét határozták el úgy, hogy a leblokkolt hengerek kiemelése után a hengerek helyére egy-egy a Maurer cég által tervezett és gyártott „Kalottenlager”-t (gömbsüveg-saru) építettek be (16. ábra). A sarucse- 


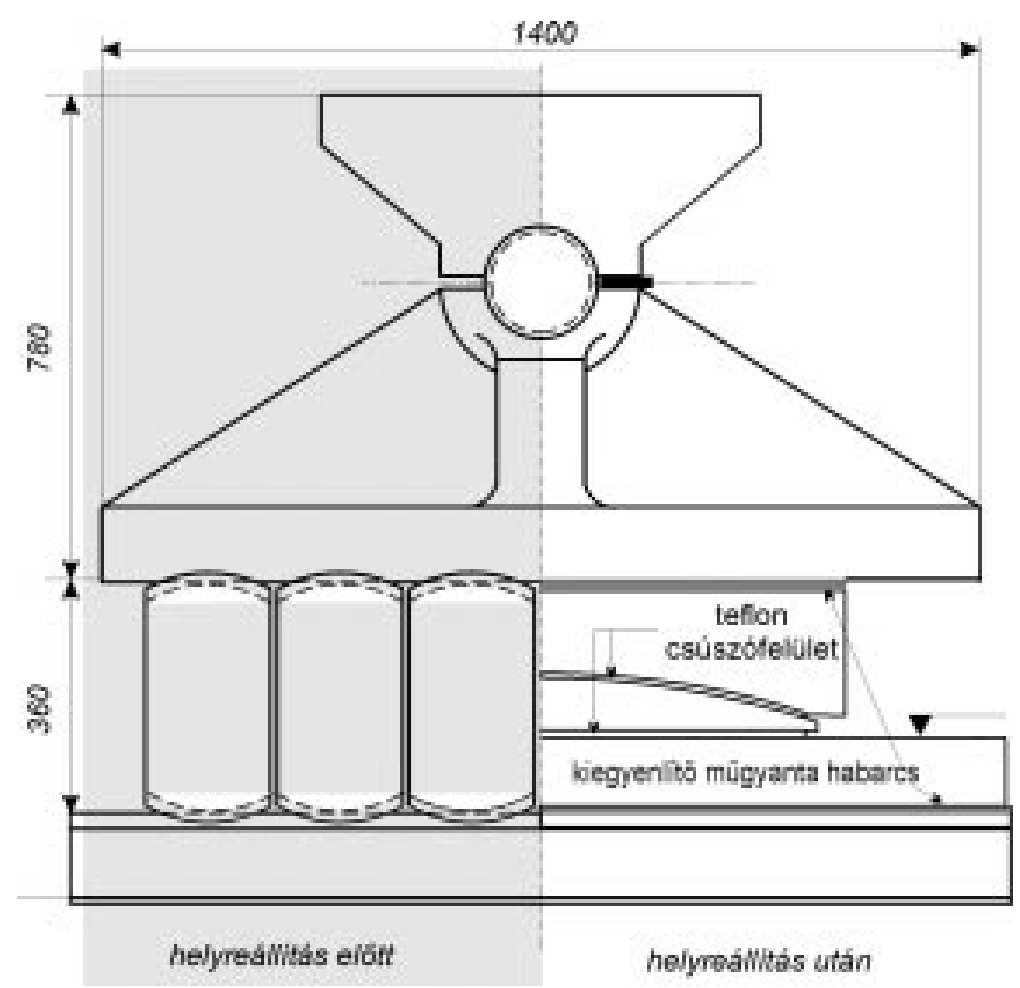

16. ábra. A Petőfi híd budai mederpillérén lévő eredeti és átalakított mozgósaruja

re végrehajtásához teljes forgalomlezárás volt szükséges, ami csak az 1995-ben megnyitott új Lágymányosi híd elkészültével volt biztosítható. A sarucsere lebonyolításának irányítására, előkészítésére, a végrehajtáshoz szükséges mérések megtervezésére és végrehajtására a Tanszék kapott megbízást [11].

A sarucsere lebonyolítását a négy főtartó egyidejü, közel párhuzamos megemelésével láttuk biztosítottnak. Ezért először a négy főtartó alá egy-egy kalodaszerüen kialakított emelőkeretet építtettünk be, amelyeknek sarokpontjain, főtartónként négy-négy hidraulikus munkahengerrel történt a szerkezet emelése. A számított reakció az önsúlyból a szélső főtartók alatt $12000 \mathrm{kN}$, a közbenső főtartók alatt $16000 \mathrm{kN}$. A saruk egyenkénti cseréjét a keresztirányban gátolt mozgású, 2. sz. főtartó alatti saru cseréjével kellett kezdeni. A sarucsere alatti minimális hőingadozás, illetve az évi középhőmérsékletnek megfelelő várható hőmérséklet érdekében a sarucserére 1996 szeptemberének második felében került sor és azt 16 nap alatt sikerült lebonyolítani. A 16 napból három szombaton és vasárnap volt lehetőség a teljes forgalomkorlátozásra, amikor a híd megemelése történt. 


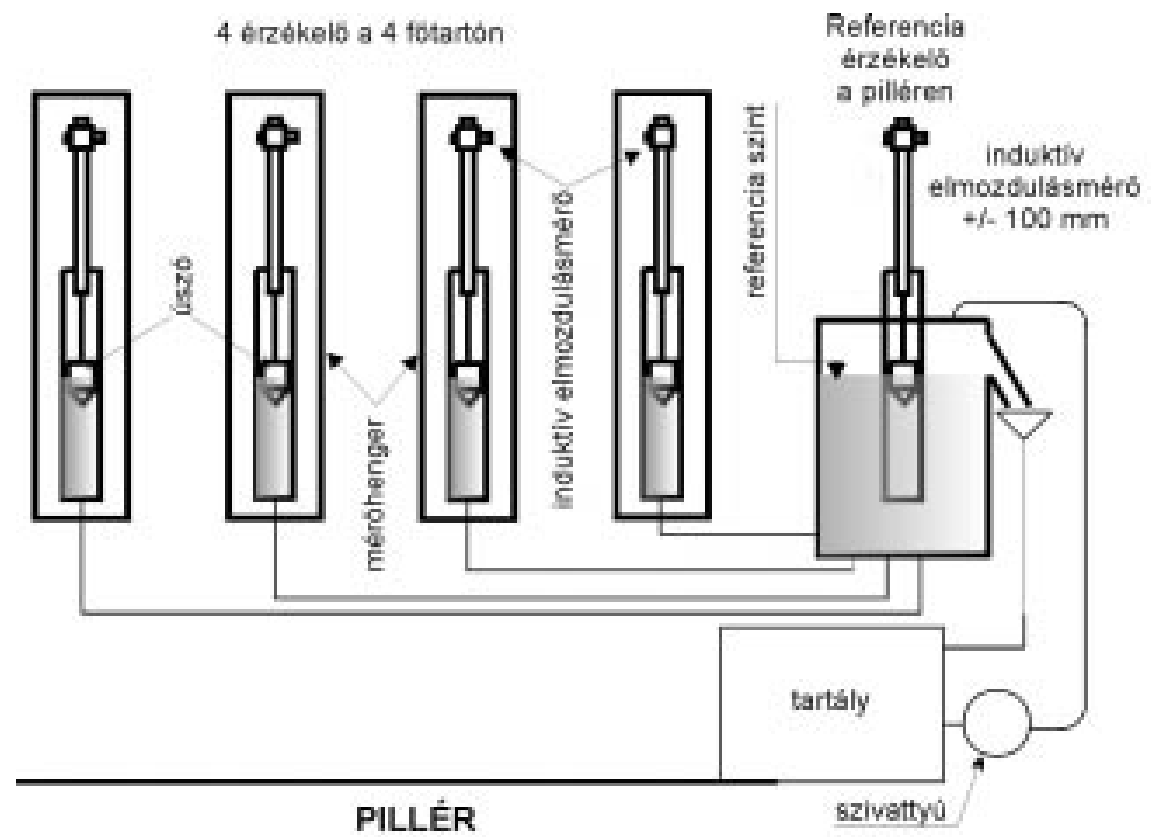

17. ábra. A Petőfi híd sarucseréjénél a főtartók emelési mértékének ellenőrzésére használt közlekedő-edényes mérőrendszer

A sarucsere végrehajtását megelőzte az összes munkahenger és tápegység laboratóriumi felülvizsgálata, a pontos végrehajtási program kidolgozása, a múgyantahabarccsal végrehajtandó, nem megismételhető aläöntés módszerének megfelelő előkísérlettel igazolt kiválasztása, valamint az erők és mozgások mérésére szolgáló olyan módszer kidolgozása, amely a mérések zavartalan lebonyolítását, illetve a sarucsere korrekt végrehajtását lehetővé tette.

A saruerők méréséhez főtartónként 4-4 munkahengert múködtető tápegységet egy-egy HBM Digibar nyomásmérővel szereltünk föl, míg a mozgásméréshez egy olyan közlekedőedényes mérési rendszert alkalmaztunk, amely egy a pillérre állított, keringtetéssel és túlfolyóval ellátott, állandó vízmagasságú víztartályból és ezzel egyenként összekapcsolt, a négy fötartóra felszerelt egy-egy vízszintmutatóból és egy a tartályra közvetlenül felszerelt referencia-vízszintmutatóból állt. A vízszint felső szintjét egy-egy W50-típusú induktív elmozdulásmérő úszó vasmagja alakított elektromos jellé (17. ábra). A mérörendszert kiegészítette egy Pt100-as ellenállás-hőmérő és az egyik fơtartó és a hídfő közé beépített W50-es induktív elmozdulásmérő. A mérőérzékelőket a 18. ábrán vázolt, folyamatosan müködő mérő- és számítógépes adatfeldolgozó rendszerrel építettük össze, ami a nedves környezet miatt a budai hídfőbe, zárt, száraz helyre került. A manipulációk alatti 


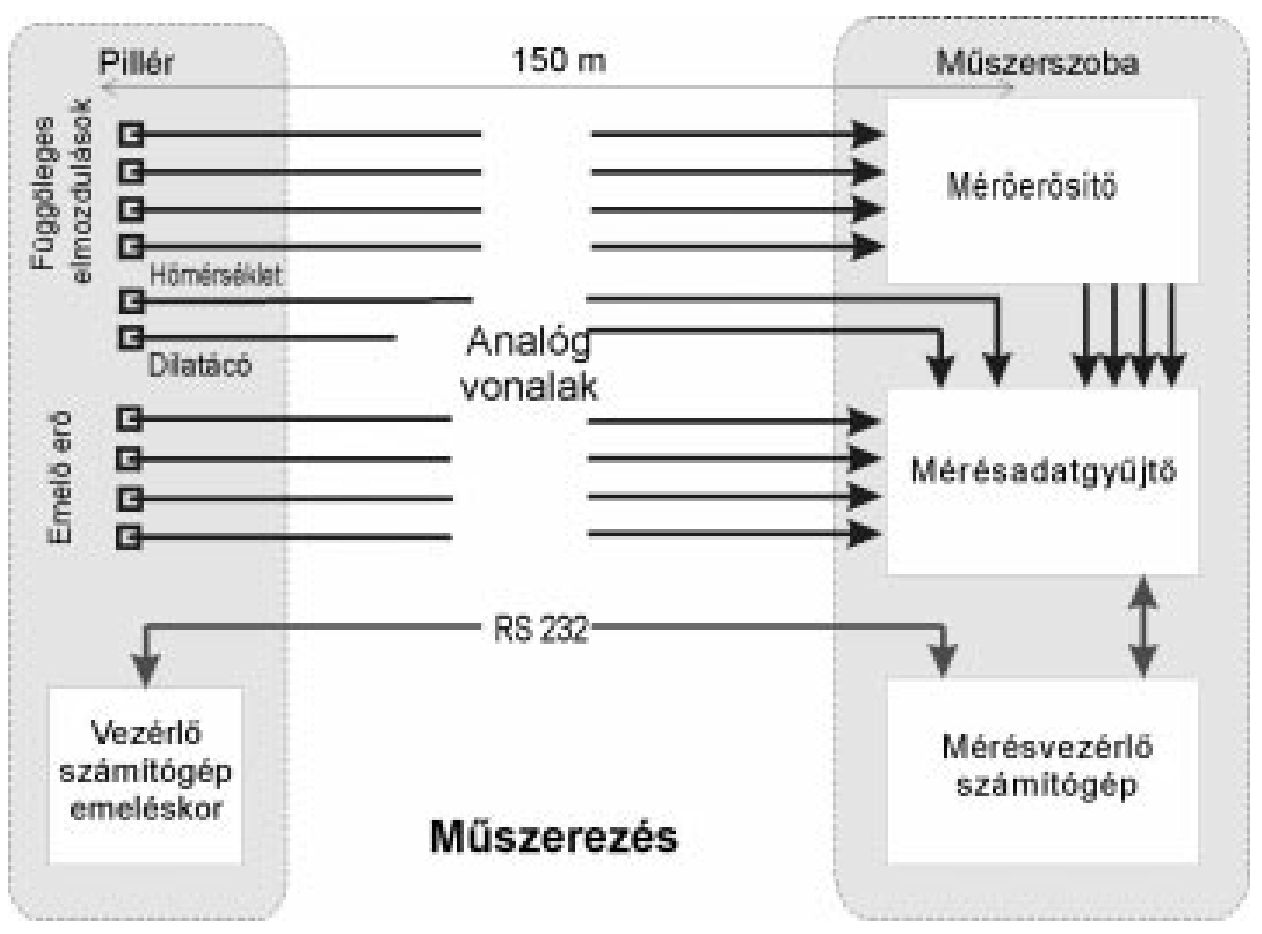

18. ábra. A Petőfi híd sarucseréjéhez összeállított mérési adatgyűjtő rendszer

mérési eredményeket a helyszínen egy notebook számítógéppel jelenítettük meg. A mérés megkezdésétől kezdve a számítógépes mérő- és adatgyưjtő rendszer folyamatosan müködött, és a mért adatokat 30 percenként rögzítette. A sarucserével kapcsolatos manipuláció alatt a leolvasási időket 4-5 sec-ra csökkentettük. Ekkor a monitoron a négy reakcióerő és a négy főtartó relatív helyzete, valamint a többi mérési adat grafikusan és numerikusan is megjelenítésre került.

Első lépésként a négy fơtartó felszakítása volt a feladat, amit a számítottnál mintegy 50 \%-kal nagyobb erőnél $83000 \mathrm{kN}$-nál sikerült elérni. Ennek okát a ferde felületeken való támaszkodásból adódó, nem tökéletes erőátadás miatt kialakuló dugattyú-befeszülésben lehet keresni. Az emelés mértéke ekkor $25 \mathrm{~mm}$ volt. A magassági állapot rögzítése után történt a részben felragadt saruhengerek lefeszítése, majd a 2. sz. sarunál a hengerek egymás utáni kihúzása. Ezután az 1., 3. és 4. jelủ saruknál a saruhengerek fölé egy-egy $14 \mathrm{~mm}$ vastag alátétlemezt csúsztatva be a hidat az eredeti állapothoz képest +15 mm-re engedtük vissza. A leeresztés után a munkahengereket minden főtartónál $4000 \mathrm{kN}$-nal befeszítettük. 
Ekkor történt meg az alsó és felső öntvény erősen rozsdás felületének letisztítása, majd a két felület helyzetének pontos felmérése. A mérések alapján kiderült, hogy a 2. sz. sarunál az oldalirányú mozgást megakadályozó lemezek nem helyezhetők el biztonságosan, ezért a következő napon a hidat újra megemelve a 3. sz. fótartó alatti saruhengerek kiemelését is megkezdtük, majd a hidat az előző állapotnál $5 \mathrm{~mm}$-rel alacsonyabb helyzetbe eresztettük vissza.

Ezután kezdődött az új 2. sz. saru elhelyezése, amely a saru hossz- és keresztirányú beállítása után a saru magassági helyzetének, azaz a csúszófelületek vízszintességének pontos beállításával fejeződött be. Így alakultak ki az új Maurer-saru alatti és feletti változó vastagságú hézagok, melyeket mügyantahabarccsal kellett kiönteni, és amelyek vastagsága $2 \mathrm{~mm}$-nél kevesebb, 20 mm-nél több sehol sem lehetett.

A pontos beállítás után kezdődött a mügyantahabarcs injektálásának előkészítése, az oldaltömítések gyorsan kötő cementhabarccsal való lezárása, az injektáló és levegőztető csonkok elhelyezése, majd a nyitott homlokfelületen keresztül a mügyantakiöntés szilárdságának növelése érdekében a 2-4 mm szemnagyságú, mosott és szárított kvarchomok sürített levegővel való befúvatása. Ennek befejezése után a homlokfelületeket is lezárták és a sarut sátorral körülvéve megkezdődött az előmelegítés. Az injektáláshoz CONCRETIN IHS típusú epoxigyantát alkalmaztak. Az injektálás során a gyantának a levegőztető csonkoknál való megjelenésekor a csonkokat egymás után lezárva addig folyt az injektálás, míg minden csonknál meg nem jelent a gyanta. Az injektálás után a saruk melegítése még 48 óráig tartott. Az injektálással egyidejűleg készített próbatestek szilárdsága a megkívánt $20 \mathrm{MPa}$-os nyomószilárdság többszöröse volt.

A 3. sz. saru előkészítése, az új saru elhelyezése és injektálása az előzőhöz hasonlóan folyt, de itt az alsó öntvénynél kisebb méretü gömbsüvegsaru miatt a régi öntvények le nem fedett felületei epoxi-alapú védőbevonatot kaptak.

Az aláöntések megszilárdulása után, a második hétvégen történt meg a 2. és 3. sz. saruk saját lábra állítása, és az 1. és 4. sz. főtartók alatti régi saruhengerek kiszerelése, az új saruk behelyezése és injektálása. Ehhez a saruk idő előtti múködésének megakadályozására a 2. és 3 . sz. főtartókat 10000 kN-nal, az 1. és 4. sz. főtartókat 4000 kN-nal feszítettük alá.

A harmadik hétvégen, szeptember 29-én történt meg a hídnak az új sarukra történő végleges leeresztése. Az új saruk viselkedésének ellenőrzésére a négy sarunál egy-egy mérőórával ellenőriztük az új saruk felső öntvényeinek függőleges és vízszintes elmozdulását. A híd lábra állítása után, ami $+13{ }^{\circ} \mathrm{C}$-nál történt meg, a hőmérséklet emelkedésével a felső öntvények rendeltetésszerúen Buda felé mozdultak el. A sarucsere teljes időtartama alatt a hőmérséklet a kívánatos $+10^{\circ} \mathrm{C}$ középhőmérséklettől lényegesen nem tért el. 


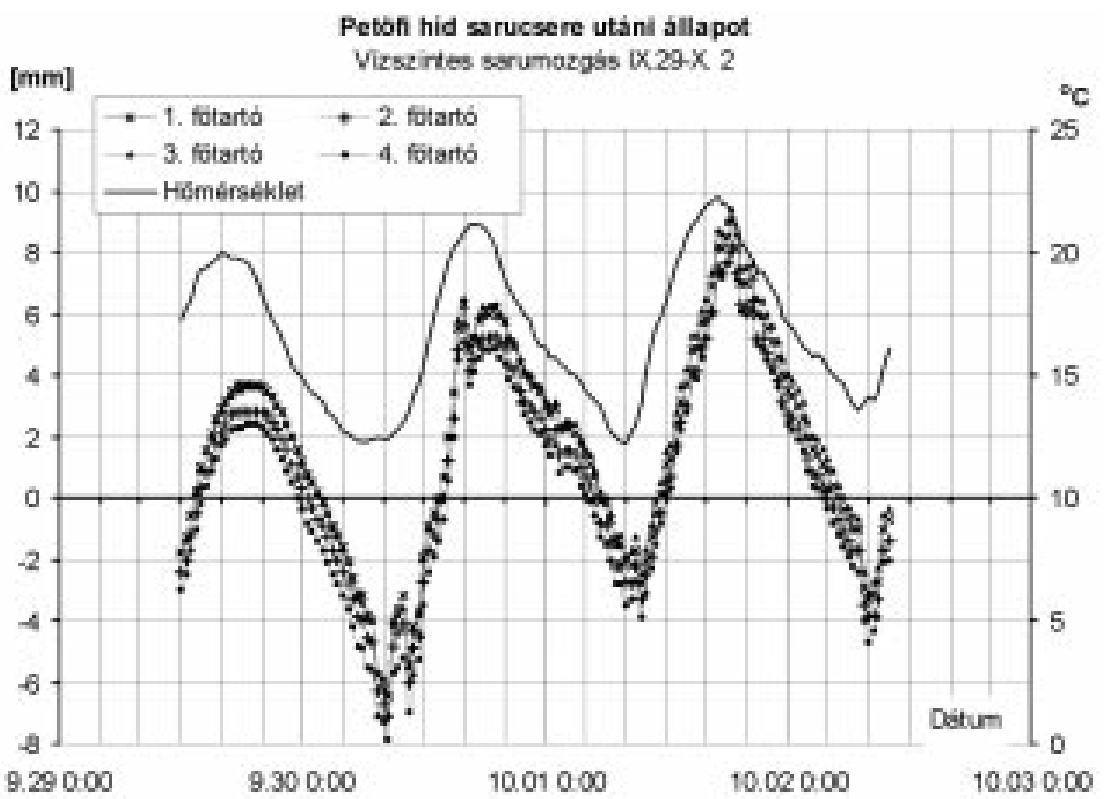

19. ábra. A híd „lábraállítása” után mért sarumozgás és a hőmérsékletváltozás összehasonlító diagramja

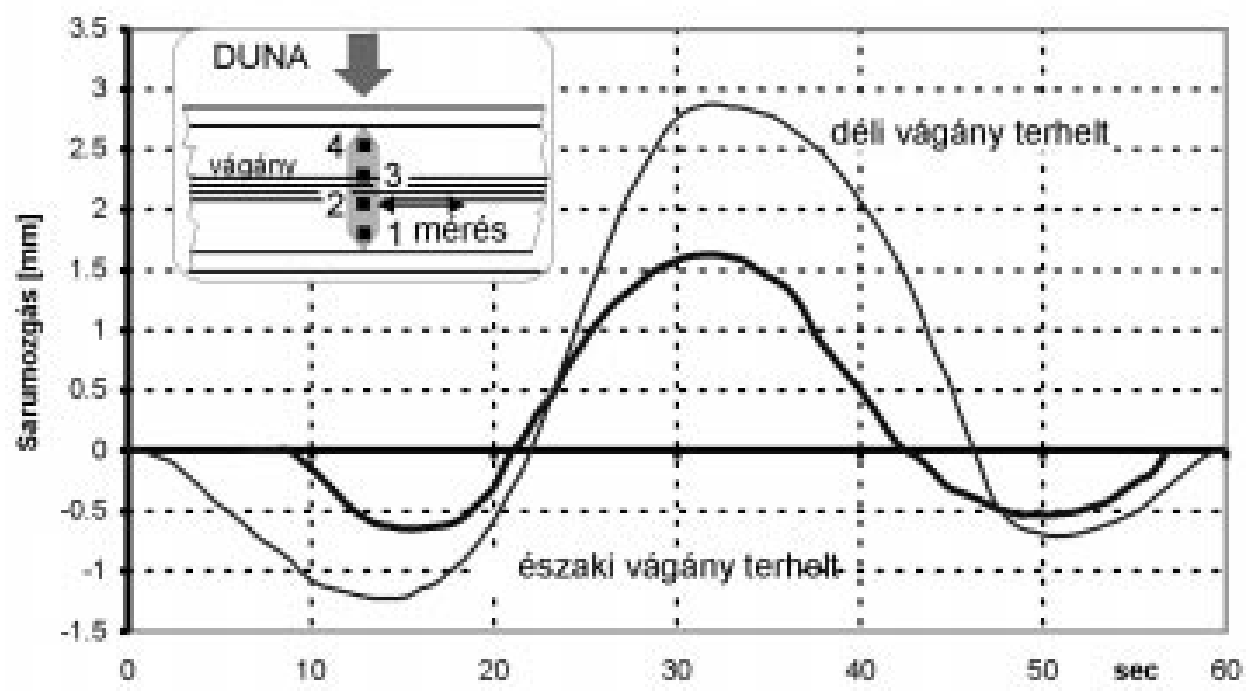

20. ábra. A 2. sz. saru hídtengely irányú mozgása a 2. és 3. jelű főtartók között lévő villamospályán haladó villamosok hatására 
A lábraállítás után mind a négy saruhoz egy-egy induktív elmozdulásmérőt szereltünk és a mérőrendszert 30 percenkénti adatrögzítésre állítottuk. A 19. ábra a leeresztést követő három nap alatt bekövetkezett mozgásokat és a hőmérsékletváltozást szemlélteti, és mutatja, hogy a hőmérsékletváltozás és sarumozgás teljes összhangban van. A diagramból az is jól látható, hogy kezdetben, amikor teljes forgalomkorlátozás volt, a sarumozgások 30 percenként rögzített pontjai folytonos görbét mutatnak, majd a korlátozott forgalom megindulása után a görbe egyenlőtlenné vált, amit a hőmérsékletváltozás mellett a forgalom hatására kialakuló sarumozgások indokolnak. Ennek a hatásnak a vizsgálatára a villamosforgalom megindulása után mértük a 2. sz. saru vízszintes mozgását. A 2. sz. saru felett haladó villamos hatására fellépő maximális mozgás $5 \mathrm{~mm}$, a 3. sz. főtartó felett haladó villamos hatására pedig $3 \mathrm{~mm}$ volt (20. ábra).

\section{IRODALOMJEGYZÉK}

[1] Szittner, A. - Halász, O.: Probebelastung einer historischen Stahlbrücke in Budapest. IABSE Symposium, Venecia, 1983. Verstärkung vom Bauwerken - Diagnose und Behandlung. Schlußbericht. IABSE-AIPC-IVBH, ETZ Hönggerberg, Zürich, 69-76.

[2] Korányi I. - Szittner A.: Ellenőrző vizsgálatok a Margit-hídon. Mélyépitéstudományi Szemle, XXVI (1976) 4. sz. 146-159.

[3] Szittner A.: A Lánchíd legutóbbi felújítása alkalmából végzett elméleti és kísérleti vizsgálatok. Közlekedés- és Mélyépitéstudományi Szemle, XL (1990) 6. sz. 217-222.

[4] Papp F.: Rúdszerkezetek síkbeli modellezésének alkalmazása a Széchenyi-lánchíd vizsgálatánál. Közlekedés- és Mélyépitéstudományi Szemle, XL (1990) 6. sz. 223-226.

[5] A. Szittner.: Model Analysis of the New "Elisabeth" Suspension Bridge in Budapest. In: Proceedings of the Conference on Experimental Methods of Investigating Stress and Strain in Structures. Praha, 1965. 376-386.

[6] Szittner A.: A Fővám-téri - Ferenc József - Szabadság-híd. Épités- Épitészettudomány, XXIII (1992-93) 3-4. sz. 267-278.

[7] Szittner A.: A Szabadság-híd rekonstrukciója. Közlekedés- és Mélyépitéstudományi Szemle, XXXVII (1987) 1. sz. 2-13.

[8] Szittner A. - Kálló M. - Köröndi L. - Kristóf L.: A Szabadság-hídon végzett vizsgálatokhoz kapcsódó mérések és az ezek alapján levonható következtetések. Közúti Közlekedés- és Mélyépitéstudományi Szemle, XLVIII (1998) 6. sz. 193-200.

[9] Szittner A. - Kálló M. - Köröndi L. - Szépe F.: A Déli Összekötő Vasúti Duna-hídon végzett próbaterheléses vizsgálatok. Közlekedésépités- és Mélyépitéstudományi Szemle, XLI (1991) 7. sz. 263-272.

[10] Szittner A. - Kaltenbach L. - Kristóf L.: Fáradási vizsgálatok vasúti hidak forgalomban volt hossztartóin. Közlekedésépités- és Mélyépitéstudományi Szemle, XLI (1991) 12. sz. 465-473.

[11] Szittner A. - Kálló M. - Kaltenbach L.: A Petőfi-híd sarucseréje. Közúti Közlekedés- és Mélyépitéstudományi Szemle, XLVII (1997) 4-5. sz. 177-186. 


\section{DIE BUDAPESTER DONAU-BRÜCKEN \\ Der jetzige Zustand der Brücken auf Grund der Untersuchungen von den letzten 40 Jahren \\ Zusammenfassung}

Der Lehrstuhl für Stahlkonstruktionen der TU Budapest beschäftigt sich etwa seit 1955 mit der experimentellen Spannungsanalyse der Trägerkonstruktionen. In diesem Referat wurden die wichtigsten, im Zusammenhang mit dem Bau, der Rekonstruktion und der Inbetriebnahme der Budapester Donau-Brücken durchgeführten Meßaufgaben und deren Resultate zusammengefaßt. Es werden die folgenden Arbeiten dargestellt: die Modelluntersuchung für die Montage der Elisabethbrücke, die bei der Probebelastung gemessene Spannungsverteilung des genieteten Versteifungsträgers, die Arbeit bei der Freiheitsbrücke im Zusammenhang mit der Verbesserung des beschädigten Pfostens 6-6', die bei der Kettenbrücke entwickelte Meßmethode und Meßinstrument, um die Korrosionsbeschädigung der Kettenglieder festzustellen, die Untersuchungen an der Eisenbahnbrücke-Süd, um die Restlebensdauer der Hauptträger und der Längsträger zu bestimmen, und zuletzt die Arbeit für die Vorbereitung und Leitung der Lagerauswechselung bei der Petőfibrücke.

Keywords: Danube-bridges, power function of bridges, reconstruction of bridges 